\title{
Shape Grammar Strategies for Representing the Built Heritage
}

\author{
Khalid Ahmed Hussein ${ }^{a^{*}}$, Emad Hani Ismaeel ${ }^{a}$ \\ ${ }^{a}$ Dept. of Architecture, Coll. of Engineering, University of Mosul, Iraq
}

\section{ARTICLE INFO}

Article history:

Received 25 June 2020

Received in revised form 7 August 2020

Accepted 16 August 2020

\section{Keywords:}

Shape Grammar

Built Heritage

Historic Buildings

Architectural Elements

Local Architecture

Digitization

\begin{abstract}
A B S T R A C T
Traditional architecture style represents the evolutionary style and experienced characteristics of the urban environment. This style includes a mixture of technical and cognitive values that are difficult to conserve compared to other material resources. One of the important means of Conservation is analyzing the deep structures of this architecture and determining their rules and constraints. On the other hand, Shape Grammar is an effective system for analyzing architecture as it combines mathematical and morphological values in architecture. The current research focuses on the problem of shape grammar strategies for each scope in architecture, in addition to determining the techniques used in the analysis, derivation, and generation of the shapes. It aims for defining the appropriate strategies of shape grammar in each scope in architecture. Thus, the significance of this research stems from the disclosure of the potential of shape grammar in analysis, generation, and representation of the built heritage in the same architectural language as a mean of Conservation. The research adopts the analysis of studies that employed the shape grammar in the built heritage. The research aim was achieved by determining the strategies of the shape grammar to analyses and represent the built heritage according to its scope.
\end{abstract}

\section{Introduction}

Historic buildings represent a high-value part of the built heritage and have a prominent role in achieving cultural excellence and local identity El Namara et al. [1]. On the other hand, Conservation is the action taken to prevent deterioration and conserve cultural and social values in minimal effective action. It embraces all acts that prolong the life of cultural and natural heritage, the object being to present, to those who use and look at historic buildings with wonder, the artistic and human messages that such buildings possess Feilden et al. [2]. Conservation aims to safeguard cultural heritage while ensuring its accessibility to present and future generations. Conservation embraces Preventive Conservation, Remedial Conservation, and Restoration ICOM et al.[3]. Preventive Conservation of cultural heritage includes many activities such as registration, planning, management, besides other aspects, also, in the management, including information management which deals with 3D representation and exchanges the information of the Built Heritage Al-Allaf et al. [4]. The traditional architecture represents a cumulative knowledge heritage resulting from construction techniques and local materials in a distinct architectural language; conservation requires defining the knowledge foundations of this architecture. Hence, several approaches have been employed to represent the knowledge of this architecture. One of the most prominent of these approaches is the Shape Grammar that analyses and classifies the architectural elements according to its common characteristic.

In architectural theory and practice, the context plays a significant role in proposing architectural principles. Contextual structure theory refers to the relationship between new buildings and the current environment during the process of adding new buildings and the restoration of the old buildings to achieve harmony and communication between the past and the present

* Corresponding author.

E-mail address: khalid.ahmed@uomosul.edu.iq (Khalid Ahmed Hussein) 
Lambe et al. [5]. Thus, the shape grammar is an essential approach to achieve Contextuality inbuilt heritage by generating new designs based on the existing architectural style without restricting the designer.

\section{Shape grammar}

Shape Grammar is a production system that generates 2D and 3D shapes based on a set of specific rules, invented by Stiny and Gips in 1972 as a production system that defines the rules of a set of designs Stiny et al. [6]. Shape Grammar has achieved great importance in architecture since the introduction of its concept. Its cognitive importance is embodied in the analysis of the architectural structures and its reproduction in the same language Angelo et al. [7]. Shape Grammar is similar to grammar rules, it is used in architecture as a tool for classification, analyzing, generation, and evaluation the productions in terms of morphological, functional, and mathematical characteristics of the same architecture, in addition to being a tool for creating new designs Stiny et al. [6]. These grammars can also evaluate the results and their participation in the same morphological, functional and special characteristics. However, it does not seek to reproduce the architectural language in all its detail, but rather describes it in its essence, and aims of forming other designs in the same architectural language [8].

The worth of shape grammar in analyzing architecture structure is attributed to its ability to combine morphological and mathematical analysis as an algorithm for analyzing the architectural structure of Angelo et al. [7]. This feature enabled the shape grammar to analyse the existing architecture in general and traditional in particular, to determine its characteristics to restore the virtual reconstruction of the architecture without changing its language. Accordingly, many international experiences studies and researches have employed the shape grammar in conservation and representation of heritage by several methodologies such as computer applications and programming languages.

\section{Recent Literatures}

For employing the shape grammar in architecture, there are many levels according to the purpose, classification mechanisms, and methodologies to formulate the results. This research highlights these aspects, focusing on employing this technique in analyzing the structure of architecture according to certain criteria. Many researches have discussed the issue of heritage components classification, including:

- Abulnour et al. [9]: The research discussed the classification of monuments according to the degree of importance in heritage, the level of deterioration, and the state of preservation.

- Orenia et al. [10]: The study deals with the heritage elements classification in the database, with a hierarchical structure that begins with general elements, decorations, and details, according to the type of elements, characteristics, timelines, and analysis of the elements suitability for reuse.

- Lagomarsino [11]: The study presented a topological classification related to damage of heritage elements in a historical building according to the degree of damages.

- Saleeb et al. [12]: The study discussed the development of a system of classification of heritage elements by comparing the current systems

This study aims to present a new concept to analyze the structure of the Architectural Heritage using Shape Grammar according to several aspects including the scope of architecture, methodology, and morphological, functional, spatial, mathematical, and typological characteristics.

\section{Hypothesis and Objectives of the Research}

The critical review of previous studies showed that shape grammar is applied in the architectural built heritage within different strategies according to the type of shape grammar, characteristics, techniques for deriving rules, and methods of generating shapes, and there is no study on classifying the strategies of shape grammar used in Built Heritage. Hence, the research problem deals with the absence of a study about strategies of applying shape grammar in different scopes in the built heritage. The research suggests that there are certain strategies for applying shape grammar in each scope of Heritage Architecture.

\section{Research Methodology}

The methodology of research adopts analyzing different studies that dealt with applying shape grammar in a different scope of urban heritage.

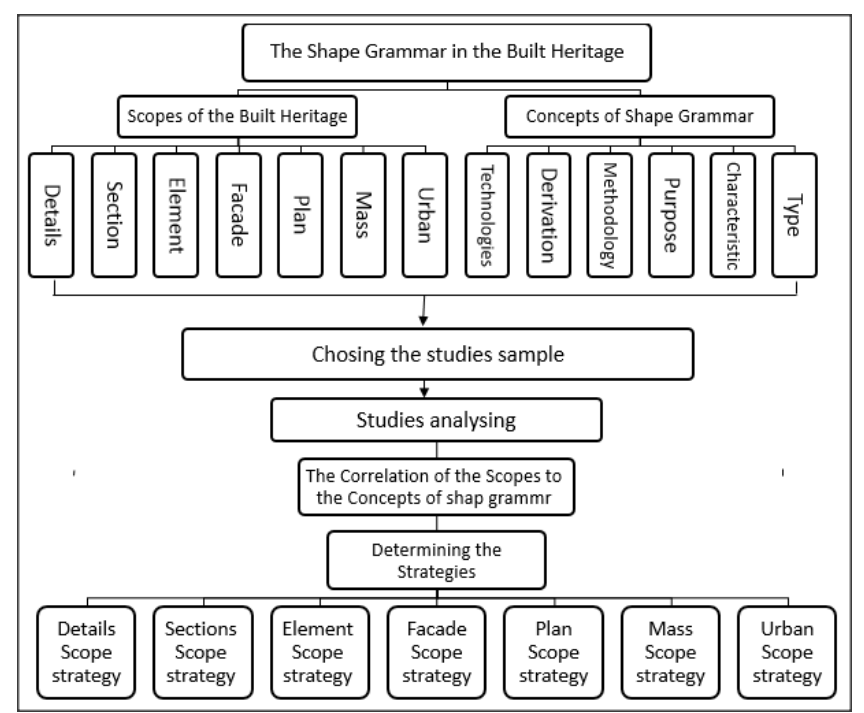

Figure 1. Research Methodology

\subsection{The Concepts of Shape grammar}

- Types of Shape Grammar Al-Jameel et al. [13]:

- Standard shape grammar: This grammar depends on applying the rules to Initial shape.

- Parametric shape grammar: This grammar applies parameters in rules to syntax new ones.

- The Characteristics

- Morphological Characteristics: Dealing with the external morphological properties

- Mathematical Characteristics: Adopting mathematical analysis to determine the proportions.

- Functional Characteristics: Determining the restriction on the functional spaces.

- Typological Characteristics: Determining the relationships between the elements.

- Spatial Characteristics: Determining the location of an element in a system or a group. 
- The Purpose of employing Shape Grammar

- Classification: Grouping the elements or styles that share the same characteristics.

- Analysing: Determining the Morphological and Mathematical Characteristics of a particular style.

- Evaluation: Determining the context of a particular element in an architectural language.

- Generation: Creating many alternatives in the same architectural language.

- The Analysing Methodology

- Traditional (Manual): Representing the characteristics and rules in a drawing process.

- Software (computer applications): Using applications in analysing digitally.

- Digital languages OWL, GDL, CITY GML, Python: Representing characteristics

- The Strategy of Formulating the Shape Grammar Benrós et al. [14]

- Top- Bottom Strategy: Defining external borders then adding or dividing the elements.

- Bottom -Top Strategy: Defining a central element then adding other elements relationally.

- Addition Strategy: Adding elements gradually according to priority to reach the final form.

- Division Strategy: Dividing the total element into other elements to reach the final form.

- Procedural Strategy: Modelling controlled by shape grammar in computer applications.

- The Technique of Applying the Shape Grammar

- City Engine: A 3D modelling application for urban scale and façade.
- SGI: Digital applications, based on shape grammar, for generation an architectural style.

- Coordination: The reference point coordinates for generating designs in a traditional method.

- Grid: A grid-based on a determined unit to apply specific shape grammar.

\subsection{Scopes of the Built Heritage}

In general, Architecture or Built Heritage can be divided into different ranges or scopes according to the level of the item of the study. These scopes have a certain level of information and characteristics, so the built heritage can be classified according to studies scopes to Jong et al. [15]:

- Studies in urban scope

- Studies in masses scope

- Studies in plan scope

- Studies in facades scope

- Studies in architectural elements scope

- Studies in architectural sections scope

- $\quad$ Studies in detail scope

The research sample was chosen from previous studies to cover all scopes of the built heritage. The selected studies cover all strategies of shape grammar in dealing with built heritage, which is the last studies was researched in this field to determine the formulating methodologies, techniques, characteristics, and strategies for deriving the grammar.

Next to selecting the studies sample and determining the concepts of the shape grammar, these studies are analyzed to determine the strategy of each scope in representation of the Built Heritage.

Table 1- Analyzing Recent Literatures and Studies According to the Shape Grammar Concepts

\begin{tabular}{|c|c|c|c|c|}
\hline S. & Sc. & The Study & Case Study & Analysis \\
\hline 1 & \multirow{3}{*}{ 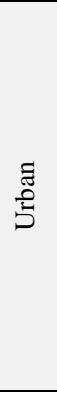 } & $\begin{array}{l}\text { Müller et al. [16] } \\
2018\end{array}$ & $\begin{array}{l}\text { The Traditional } \\
\text { Roman urban in } \\
\text { Pompeii }\end{array}$ & $\begin{array}{l}\text { Classifying the urban components based on GIS data. } \\
\text { Classifying the sectors according to the density, coverage ratio, and function. } \\
\text { Formulating the distribution grammar of areas and street network. } \\
\text { Importing façades grammar from the digital library using City Engine }\end{array}$ \\
\hline 2 & & $\begin{array}{l}\text { Zhu et al. [17] } \\
2015\end{array}$ & $\begin{array}{l}\text { 3D modelling of } \\
\text { urban façade in } \\
\text { Shanghai }\end{array}$ & $\begin{array}{l}\text { Collecting Data and analysis it by Google Earth via photography. } \\
\text { Using the City Engine to create a 3D model of the building. } \\
\text { Using the facade rule in City Engine to create the automatic grammar CGA. }\end{array}$ \\
\hline 3 & & $\begin{array}{l}\text { Di Angelo et al. [18] } \\
2012\end{array}$ & $\begin{array}{l}\text { The Traditional } \\
\text { Bali residences }\end{array}$ & $\begin{array}{l}\text { Formulating grammar from urban level to the building blocks distributions by determining } \\
\text { the direction, intensity, organization, and function. } \\
\text { Arranging the wings of the house according to the space hierarchy. } \\
\text { Other details of the decoration that include stones, pillars, roof elements, etc. }\end{array}$ \\
\hline 4 & \multirow{4}{*}{ 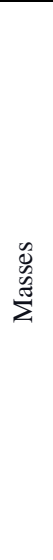 } & $\begin{array}{l}\text { SASS et al. [19] } \\
2007\end{array}$ & $\begin{array}{l}\text { The prototype } \\
\text { in } 3 \mathrm{D} \text { printing }\end{array}$ & $\begin{array}{l}\text { Classifying elements into walls, columns, windows, ceiling, frieze, additions, stairs, doors, } \\
\text { details, then Symbolizing them. } \\
\text { Formulating shape grammar to determine the o components placement in two types, } \\
\text { morphological for the element and relational between them. }\end{array}$ \\
\hline 5 & & $\begin{array}{l}\text { Trescak et al. [20] } \\
2012\end{array}$ & $\begin{array}{l}\text { The Traditional } \\
\text { Church in } \\
\text { Danube }\end{array}$ & $\begin{array}{l}\text { The research applies two types of algorithms, the first is the tree search algorithms and the } \\
\text { second is the optimal detection algorithm for the style. } \\
\text { The research provides an SGI tool for an automatic creation of designs. }\end{array}$ \\
\hline 6 & & $\begin{array}{l}\text { Tepavčević et al. [21] } \\
2013\end{array}$ & $\begin{array}{l}\text { A Group of } \\
\text { heritage } \\
\text { churches in } \\
\text { France }\end{array}$ & $\begin{array}{l}\text { Statistical analysing of the morphological characteristics by the multiple comparison } \\
\text { method. } \\
\text { Representing the characteristics according to dimensions, Relationships, and Categories } \\
\text { Classifying of grammars into: morphological and typological grammar. } \\
\text { Apply CGA grammar in procedural methodology using City Engine. }\end{array}$ \\
\hline 7 & & $\begin{array}{l}\text { ŞENER et al. [22] } \\
2008\end{array}$ & $\begin{array}{l}\text { The Ottoman } \\
\text { mosques }\end{array}$ & $\begin{array}{l}\text { Classifying the mosque into the structural system, functional and connecting components. } \\
\text { Determining the central dome which restrict relations with the other element. } \\
\text { Mathematical analysis to determine proportional systems. } \\
\text { Determining the Hierarchy of components to avoid clashes. }\end{array}$ \\
\hline
\end{tabular}




\begin{tabular}{|c|c|c|c|c|}
\hline 8 & & $\begin{array}{l}\text { Colucci et al. [23] } \\
2020\end{array}$ & $\begin{array}{l}\text { Lorenzo Church } \\
\text { in Norcia (Italy) }\end{array}$ & $\begin{array}{l}\text { Classifying the heritage elements according to the morphological and spatial characteristics. } \\
\text { Relational and conceptual analysis of the elements using GIS } \\
\text { Modelling the element with city GML language }\end{array}$ \\
\hline 9 & & $\begin{array}{l}\text { Çağdaş et al. [24] } \\
1996\end{array}$ & $\begin{array}{l}\text { The Traditional } \\
\text { Turkish houses }\end{array}$ & $\begin{array}{l}\text { Determining the main spaces that include: Rooms, Stairs, and Halls. } \\
\text { Classifying the dwellings according to the three components relationship. } \\
\text { Classifying the plan according to morphology to L, O, =, -,+, I, H, U. } \\
\text { Typological analysis: the corner, the partial, and the integral relationships. }\end{array}$ \\
\hline 10 & & $\begin{array}{l}\text { Stiny et al. [6] } \\
1978\end{array}$ & $\begin{array}{l}\text { Palladian villas } \\
\text { style }\end{array}$ & $\begin{array}{l}\text { Determining the grid and the axis to define the units in specific dimensions. } \\
\text { Determining of the outer wall that is restricted by the grid. } \\
\text { Planning the spaces that depend on the grid in a rectangular or T or }+ \text { shape. } \\
\text { Determining the main entrances: by its relationship with the axes and halls. } \\
\text { Determining the column locations in the facade. } \\
\text { Locating the openings that include windows and doors. }\end{array}$ \\
\hline 11 & & $\begin{array}{l}\text { Ahmed et al. [9] } \\
2004\end{array}$ & $\begin{array}{l}\text { Group of } \\
\text { Caravansaries } \\
\text { in Central Asia }\end{array}$ & $\begin{array}{l}\text { Classifying the components according to the morphological characteristics and spatial } \\
\text { elements. } \\
\text { Classifying the plan into: the simple, the multi-cell, and the complex plan. } \\
\text { Typological analysis of the spatial elements to determine its relationships. } \\
\text { Defining the spatial constraints to limit irrational applications. } \\
\text { Formulating the grammar: the boundaries, the cell, the fort, and the entrance }\end{array}$ \\
\hline 12 & & $\begin{array}{l}\text { Eilouti et al. [25] } \\
2012\end{array}$ & $\begin{array}{l}\text { The Traditional } \\
\text { Damascene } \\
\text { house }\end{array}$ & $\begin{array}{l}\text { Classifying the elements according to the functional, morphological and typological analysis. } \\
\text { Organizing the plans according to the functional, and spatial characteristics. } \\
\text { Mathematical analysing of the plan by parameters. } \\
\text { Formulating the shape grammar from the bottom to top. } \\
\text { Evaluating the grammars to derive new plans in the same traditional style. }\end{array}$ \\
\hline 13 & & $\begin{array}{l}\text { Abdul Raheem et al. } \\
{[26]} \\
2016\end{array}$ & $\begin{array}{l}\text { The Traditional } \\
\text { Suakin housing }\end{array}$ & $\begin{array}{l}\text { Classifying the elements according to functional and spatial characteristics. } \\
\text { Representing the initial shape in the coordinate } \mathrm{X}, \mathrm{Y} \text {. } \\
\text { Determining the parameters to modify and derive new forms. } \\
\text { Formulating the functional, spatial, and mathematical grammar. }\end{array}$ \\
\hline 14 & $\frac{\tilde{\Xi}}{2}$ & $\begin{array}{l}\text { Andaroodia et al. [27] } \\
2006\end{array}$ & $\begin{array}{l}\text { The caravansary } \\
\text { in Iran }\end{array}$ & $\begin{array}{l}\text { Classifying the building style according to the determined characteristics. } \\
\text { Analysing the morphological characteristic of the plans: orientation, axis, entrance, and } \\
\text { spatial organization of the components. } \\
\text { Verification process includes: the courtyard, the iwan, the entrance, rooms adjacent to the } \\
\text { courtyard, the room behind the iwan, and the towers. } \\
\text { Formulating the shape grammars. }\end{array}$ \\
\hline 15 & & $\begin{array}{l}\text { Eilouti et al. [28] } \\
2007\end{array}$ & $\begin{array}{l}\text { The Education } \\
\text { Buildings in } \\
\text { Mamluk } \\
\text { Architecture }\end{array}$ & $\begin{array}{l}\text { Determining the morphological characteristics: symmetry, proportionality, axes, and } \\
\text { transformation. } \\
\text { Classifying the main components according to the functional analysis. } \\
\text { Analysing the structure of the plan to determine spatial relationships. } \\
\text { Formulating the grammar. }\end{array}$ \\
\hline 16 & & $\begin{array}{l}\text { Colakoglu et al. [29] } \\
2000\end{array}$ & $\begin{array}{l}\text { The Traditional } \\
\text { Housing -Hayat } \\
\text { style }\end{array}$ & $\begin{array}{l}\text { Classifying the housing according to morphological, functional, and Mathematical } \\
\text { characteristics. } \\
\text { Generating new designs by Euclidean transformation, Parameters. } \\
\text { Determine the spatial relationships between the main elements. } \\
\text { Formulating the grammar that represent the styles of housing: A, B, and C } \\
\text { Appling the grammar in five stages. }\end{array}$ \\
\hline 17 & & $\begin{array}{l}\text { Chiou et al. [30] } \\
1996\end{array}$ & $\begin{array}{l}\text { The Traditional } \\
\text { Taiwanese } \\
\text { houses }\end{array}$ & $\begin{array}{l}\text { Determining the mathematical systems in ancient Chinese architecture. } \\
\text { Classifying the temples into: basic, longitudinal, central, and complex types. } \\
\text { Determining the proportional relationships between the components. } \\
\text { Determining the origin point } 0,0 \text {, by the label }(*) \text {, add the central room. }\end{array}$ \\
\hline 18 & & $\begin{array}{l}\text { Benros et al. [14] } \\
2018\end{array}$ & $\begin{array}{l}\text { Palladian villa, } \\
\text { Malagueira } \\
\text { houses, and } \\
\text { Prairie housing }\end{array}$ & $\begin{array}{l}\text { Comparing the three shape grammar methodologies to form an effective methodology by the } \\
\text { following operations: Addition - Union - Subtraction. } \\
\text { Formulating the grammar of Palladian villa by top to bottom strategy. } \\
\text { Formulating the grammar of Malagueira by top to bottom strategy. } \\
\text { Formulating the shape grammar of Prairie housing by bottom to top strategy. } \\
\text { Apply the new methodology to produce a new design. }\end{array}$ \\
\hline 19 & & $\begin{array}{l}\text { Al-Jameel et al. [13] } \\
2014\end{array}$ & $\begin{array}{l}\text { A Sample of } \\
\text { Islamic } \\
\text { mosques }\end{array}$ & $\begin{array}{l}\text { Classifying the common elements into the outer borders, the chapel, the courtyard, the } \\
\text { secondary spaces (arcades), and spatial elements. } \\
\text { Analysing the geometric and morphological characteristics, then make a Topological } \\
\text { analysis. } \\
\text { Formulating the grammar by this strategy: top-down, addition, and division. }\end{array}$ \\
\hline 20 & $\stackrel{\tilde{\tilde{\sigma}}}{\tilde{\pi}}$ & $\begin{array}{l}\text { Kitsakis et al. [31] } \\
2017\end{array}$ & $\begin{array}{l}\text { The Traditional } \\
\text { Greek housing } \\
\text { in Zagori }\end{array}$ & $\begin{array}{l}\text { Classifying the element according to morphological and mathematical. } \\
\text { Determining the level of detail LOD to: LOD1, LOD2, and LOD3. } \\
\text { Formulating the grammar by this strategy: top-down }\end{array}$ \\
\hline 21 & שٓ & $\begin{array}{l}\text { Calogero et al.[32] } \\
2013\end{array}$ & $\begin{array}{l}\text { The eastern } \\
\text { wing of the } \\
\text { Louvre. }\end{array}$ & $\begin{array}{l}\text { Collecting and representing the data using the basic polygons. } \\
\text { Analysing the morphological characteristics of the museum facade. } \\
\text { Applying the grammar using City Engine after creating it in OBJ format. }\end{array}$ \\
\hline
\end{tabular}




\begin{tabular}{|c|c|c|c|c|}
\hline & & & & Exporting object models to build and display the new facade. \\
\hline 22 & & $\begin{array}{l}\text { De Godo et al.i [33] } \\
2006\end{array}$ & $\begin{array}{l}\text { The Façade of } \\
\text { historical areas } \\
\text { in Brazil }\end{array}$ & $\begin{array}{l}\text { Determining the facades, followed by a metric and morphological analysis. } \\
\text { Classifying the facade element according to the analyses. } \\
\text { Setting the elements inclusion priorities. } \\
\text { Formulating the grammar from top to bottom, by inserting the initial shape }\end{array}$ \\
\hline 23 & & $\begin{array}{l}\text { Lambe et al. [5] } \\
2017\end{array}$ & $\begin{array}{l}\text { The Traditional } \\
\text { Pol residences } \\
\text { in Ahmedabad }\end{array}$ & $\begin{array}{l}\text { Analysing the plans to classify them to the spatial and functional spaces. } \\
\text { Determining the priority of applying the grammar: the central space courtyard, then the living } \\
\text { space, balcony, kitchen, iwan, porch columns, arches, upper floors, and roof. }\end{array}$ \\
\hline 24 & & $\begin{array}{l}\text { Ria et al. [34] } \\
2016\end{array}$ & $\begin{array}{l}\text { A Group of } \\
\text { virtual models }\end{array}$ & $\begin{array}{l}\text { Classifying the houses according to originality, composition, and morphological } \\
\text { characteristics. } \\
\text { Determining the primary and secondary components. } \\
\text { Applying the grammar with modifying the transformations such as repetition by the Delphi } \\
\text { program. }\end{array}$ \\
\hline 25 & \multirow{6}{*}{ 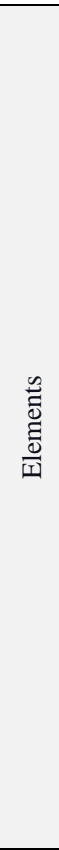 } & $\begin{array}{l}\text { Coutinho et al. [35] } \\
2013\end{array}$ & $\begin{array}{l}\text { The } \\
\text { architectural } \\
\text { elements in the } \\
\text { Florence region }\end{array}$ & $\begin{array}{l}\text { Dividing the column into the components: base, body, crown, and details. } \\
\text { Classifying columns into: Tuscan, Doric, Ionic, Corinthian, and Composite. } \\
\text { Formulating the shape grammar of components, } \\
\text { Applying the grammar in the City Engine. }\end{array}$ \\
\hline 26 & & $\begin{array}{l}\text { Al-Kazzaz et al. [36] } \\
2011\end{array}$ & $\begin{array}{l}\text { A group of } \\
\text { Islamic } \\
\text { Minarets }\end{array}$ & $\begin{array}{l}\text { Determining the components of the element from bottom to top. } \\
\text { Formulating the original grammar, then the sub-grammar. } \\
\text { Mathematical analysis by determining the by the parameters. } \\
\text { Applying and testing hybrid designs in the standards of innovation. }\end{array}$ \\
\hline 27 & & $\begin{array}{l}\text { D'Oliveira et al. [37] } \\
2012\end{array}$ & $\begin{array}{l}\text { A Group of } \\
\text { heritage } \\
\text { columns }\end{array}$ & $\begin{array}{l}\text { Determining the shape grammar for classified elements. } \\
\text { Create an identifying structure for shapes by parameters. } \\
\text { Mathematical analysis of elements to elicit mathematical equations. } \\
\text { Applying the grammar and evaluating the results. }\end{array}$ \\
\hline 28 & & $\begin{array}{l}\text { Marzouk et al. [38] } \\
2018\end{array}$ & $\begin{array}{l}\text { Heritage } \\
\text { building in } \\
\text { Egypt }\end{array}$ & $\begin{array}{l}\text { Developing the concepts of classifying elements according to the style. } \\
\text { Creating a methodology for the functional, and structural characteristics. } \\
\text { Classifying Elements into Structural elements, associated with structure and Stand-alone }\end{array}$ \\
\hline 29 & & $\begin{array}{l}\text { Ismaeel et al. [39] } \\
2014\end{array}$ & $\begin{array}{l}\text { The Residential } \\
\text { entrance in the } \\
\text { Mosul }\end{array}$ & $\begin{array}{l}\text { Classifying the design characteristics into primary, and secondary. } \\
\text { Classifying elements into: doorstep, column bases, column body, column crown, entrance } \\
\text { lintel or arch, engraving over lintel, frieze or cornice. } \\
\text { Classifying the entrance according to morphological characteristics and the components into: } \\
\text { primary entrances, and composite entrances. }\end{array}$ \\
\hline 30 & & $\begin{array}{l}\text { Garavaglia et al. [40] } \\
2020\end{array}$ & $\begin{array}{l}\text { Cuccagna } \\
\text { Farmhouse in } \\
\text { Milan }\end{array}$ & $\begin{array}{l}\text { Classifying the heritage elements according to their morphological and functional } \\
\text { characteristics. } \\
\text { Analysing the heritage elements according to their relational characteristic. } \\
\text { Scanning with Laser then modelling within BIM. }\end{array}$ \\
\hline 31 & \multirow{2}{*}{$\stackrel{0}{0}$} & $\begin{array}{l}\text { Said et al. [41] } \\
2008\end{array}$ & $\begin{array}{l}\text { The Traditional } \\
\text { Malay housing } \\
\text { TM }\end{array}$ & $\begin{array}{l}\text { Organizing the styles in hierarchy way from the simplest to the complex. } \\
\text { Determining the central unit in these dwellings and the spaces attached to it. } \\
\text { Classifying the elements according to the functional analysis. } \\
\text { Classifying the style according to the space's relationships }\end{array}$ \\
\hline 32 & & $\begin{array}{l}\text { Chiou et al. [42] } \\
1995\end{array}$ & $\begin{array}{l}\text { A Group of } \\
\text { heritage } \\
\text { elements in } \\
\text { Chinese } \\
\text { architecture }\end{array}$ & $\begin{array}{l}\text { Determining the initial shape, which is symbolized by a label. } \\
\text { Determining The composition of the room, by grammar. } \\
\text { Adding doors and windows to the central room by its parameters } \mathrm{h}, \mathrm{w}, \mathrm{u} \text {. } \\
\text { Compositing the main building plan, which includes } 7 \text { grammars. } \\
\text { Determine the ceiling according to the shape of the roof, the number of layers }\end{array}$ \\
\hline 33 & \multirow[b]{2}{*}{ 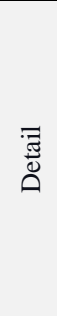 } & $\begin{array}{l}\text { Sayed et al. [43] } \\
2015\end{array}$ & Islamic motifs & $\begin{array}{l}\text { Selecting the initial shape represented by polygons, then applying the transformation by the } \\
\text { parameter that controls the position and transformation operation. } \\
\text { The shape grammar was formulated in Maya program using Python }\end{array}$ \\
\hline 34 & & $\begin{array}{l}\text { Yavuz et al. [44] } \\
2016\end{array}$ & $\begin{array}{l}\text { The Brick } \\
\text { patterns in } \\
\text { Anatolia } \\
\text { facades }\end{array}$ & $\begin{array}{l}\text { Classifying the facades that use bricks according to the shape, dimensions, transformation } \\
\text { ratios, and the characteristics of the brick units. } \\
\text { Determining the basic parameters. } \\
\text { Classifying the patterns of arrangement of brick units: Horizontal Piling / Plain Facing, } \\
\text { Horizontal-Vertical Piling / V-Wave Facing, and Oblique Piling / Spica Facing. } \\
\text { Applying the grammars to produce new patterns. }\end{array}$ \\
\hline
\end{tabular}


Next to determining the concepts of the shape grammar that includes the methodology, technique, and strategy for each scope of architecture, the studies are analyzed according to the concept of the shape grammar and the built heritage scopes as shown in Table 2 .

Table 2- Analyzing the Studies According to the concept of the shape grammar and the built heritage scopes

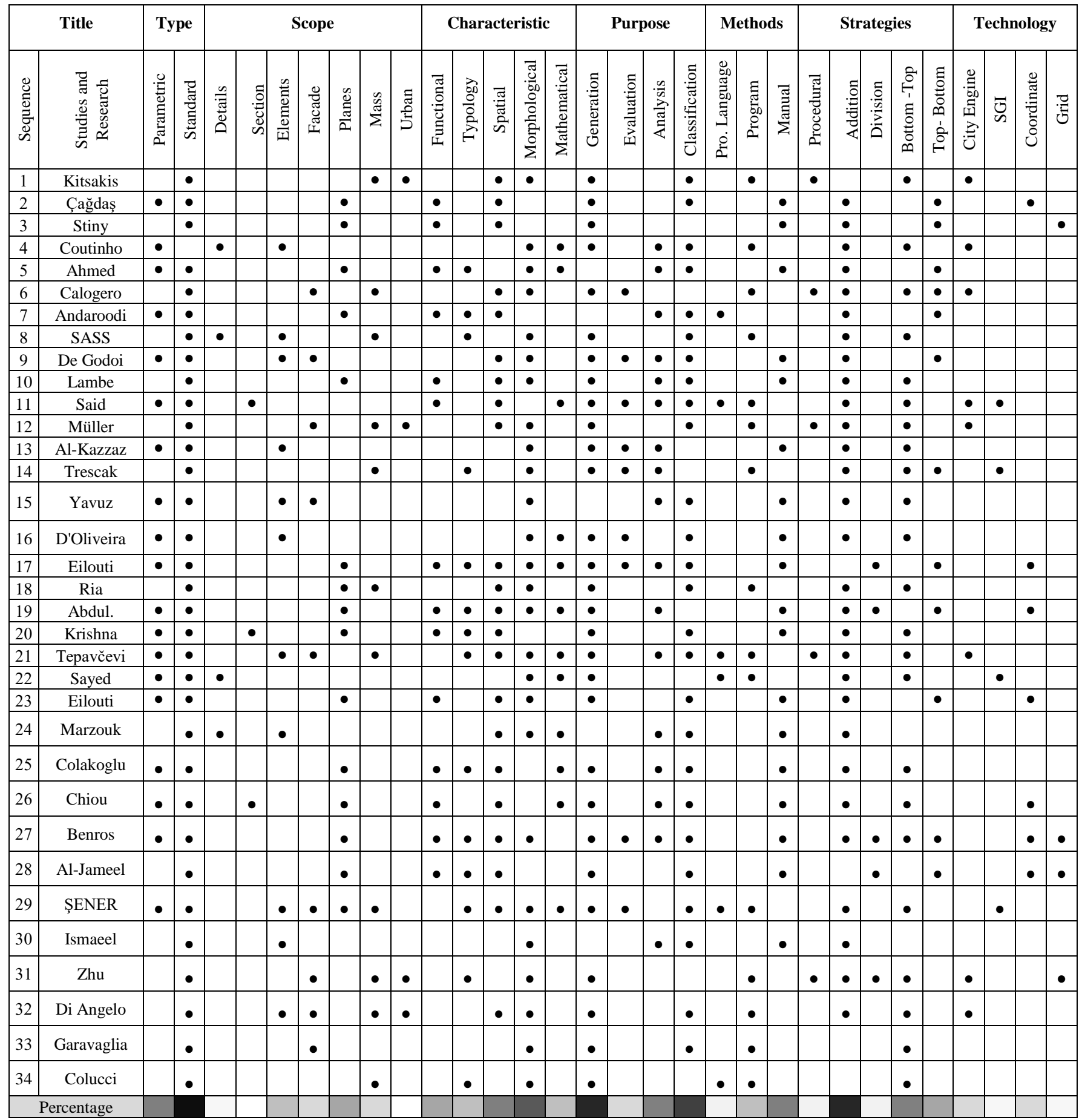


Table 3-The Correlation Results of Architecture Scope with The Techniques and Strategies, Purpose, Types, and Characteristic of Shape Grammar

\begin{tabular}{|c|c|c|c|c|c|c|c|c|c|c|c|c|c|c|c|c|c|c|c|c|c|c|c|}
\hline & \multicolumn{2}{|c|}{ Type } & \multicolumn{5}{|c|}{ Characteristic } & \multicolumn{4}{|c|}{ Purpose } & \multicolumn{3}{|c|}{ Methods } & \multicolumn{5}{|c|}{ Strategies } & \multicolumn{4}{|c|}{ Technology } \\
\hline & 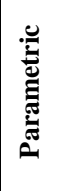 & 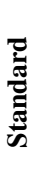 & 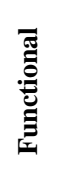 & हो & 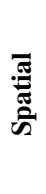 & 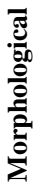 & 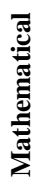 & 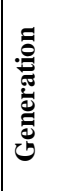 & 㺼 & $\begin{array}{l}\frac{n}{2} \\
\frac{2}{2} \\
\frac{\pi}{\pi} \\
\frac{\pi}{4}\end{array}$ & 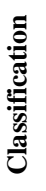 & 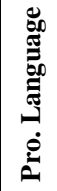 & 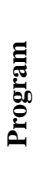 & 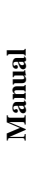 & 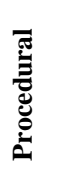 & 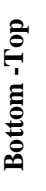 & 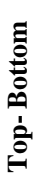 & $\begin{array}{l}\frac{0}{0} \\
: \frac{0}{20} \\
\frac{0}{0}\end{array}$ & 童 & 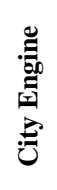 & $\underset{W}{~}$ & نُّ & 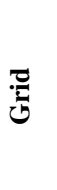 \\
\hline Urban & 0 & 99 & 0 & 25 & 66 & 99 & 0 & 99 & 0 & 50 & 75 & 0 & 99 & 0 & 75 & 75 & 25 & 0 & 75 & 50 & 0 & 0 & 0 \\
\hline Mass & 20 & 99 & 10 & 50 & 70 & 99 & 20 & 99 & 30 & 20 & 70 & 20 & 99 & 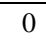 & 50 & 90 & 10 & 0 & 90 & 60 & 30 & 0 & 0 \\
\hline Planes & 73 & 99 & 80 & 60 & 93 & 50 & 40 & 86 & 20 & 53 & 80 & 13 & 13 & 87 & 0 & 47 & 53 & 27 & 87 & 0 & 6 & 46 & 20 \\
\hline Facade & 50 & 99 & 13 & 37 & 75 & 99 & 25 & 87 & 37 & 37 & 75 & 25 & 75 & 25 & 50 & 87 & 13 & 0 & 99 & 50 & 13 & 0 & 13 \\
\hline Element & 63 & 99 & 0 & 27 & 45 & 99 & 45 & 73 & 36 & 55 & 90 & 18 & 45 & 55 & 18 & 91 & 9 & 0 & 99 & 27 & 9 & 0 & 9 \\
\hline Section & 99 & 99 & 99 & 33 & 99 & 0 & 66 & 99 & 33 & 66 & 99 & 33 & 33 & 66 & 33 & 99 & 0 & 0 & 99 & 0 & 33 & 33 & 0 \\
\hline Details & 50 & 99 & 0 & 25 & 25 & 99 & 75 & 75 & 0 & 50 & 75 & 25 & 75 & 25 & 0 & 75 & 25 & 0 & 99 & 0 & 25 & 0 & 0 \\
\hline
\end{tabular}

\section{Findings}

By analyzing the previous studies, it is noted that some concepts of shape grammar are related to the type of studies in terms of the architecture scope, the techniques, and strategies used in the analyzing process. The percentage of correlation of the dependent variable (methodology, technique, strategy, purpose, type, and characteristics) with the independent variable (the scope of the study) were calculated to determine the most suitable approach for each scope.

A Below Graphical analysis for the correlation of the independent variable with the variable of shape grammar is given below.

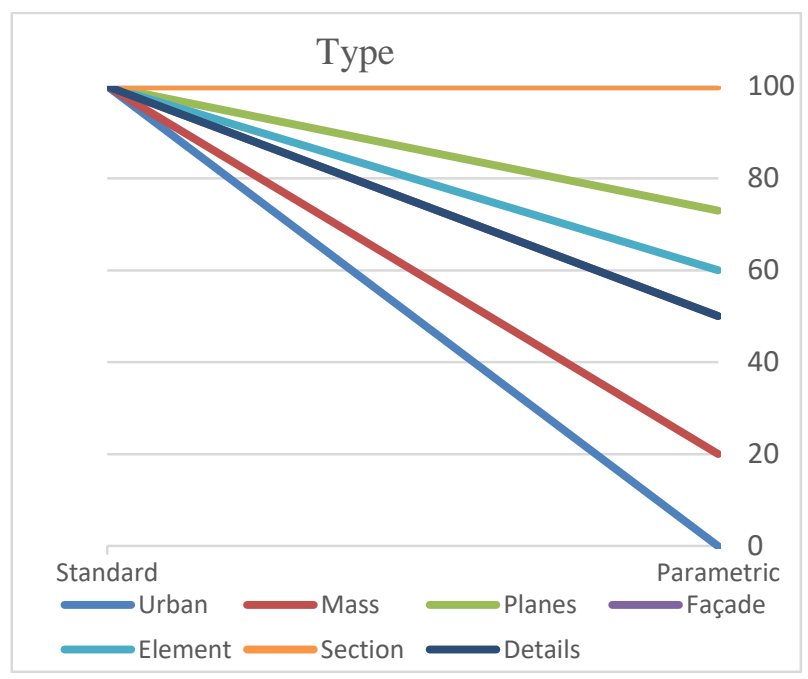

Figure 1 - Analysis of the Variables of Type in the Studies

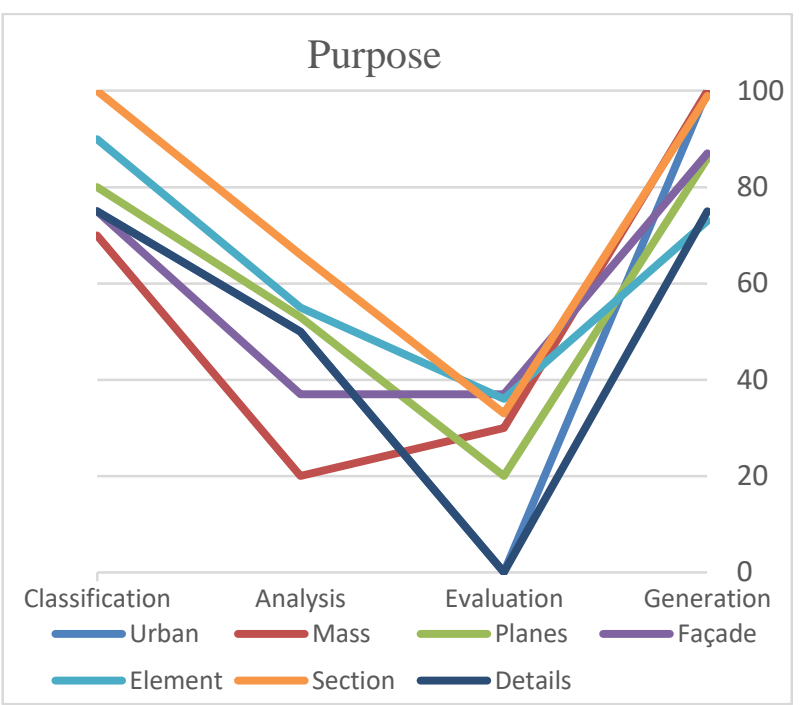

Figure 2 - Analysis of the Variables of Purpose in the Studies

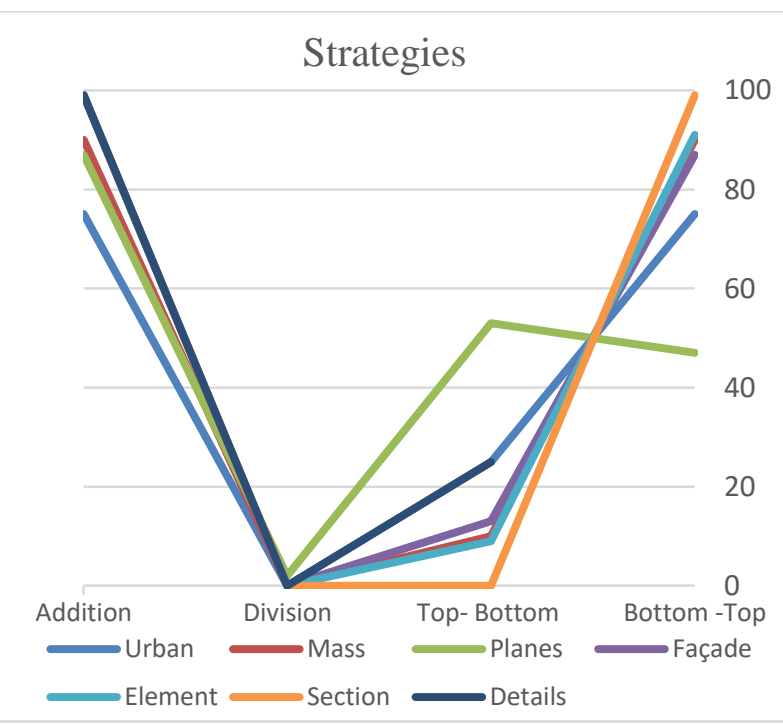

Figure 3- Analysis of the Variables of Strategies in the Studies 


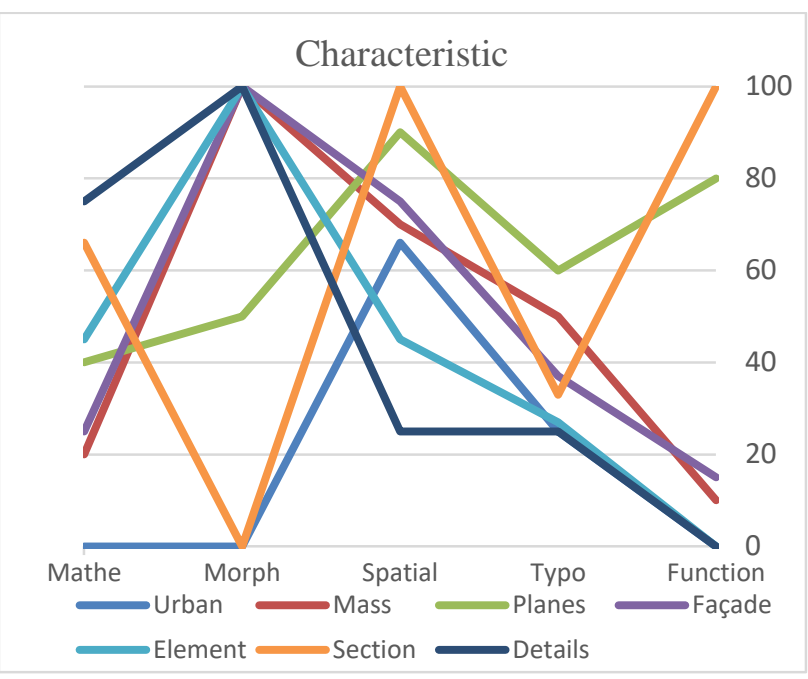

Figure 4 - Analysis of the Variables of Characteristics in the Studies

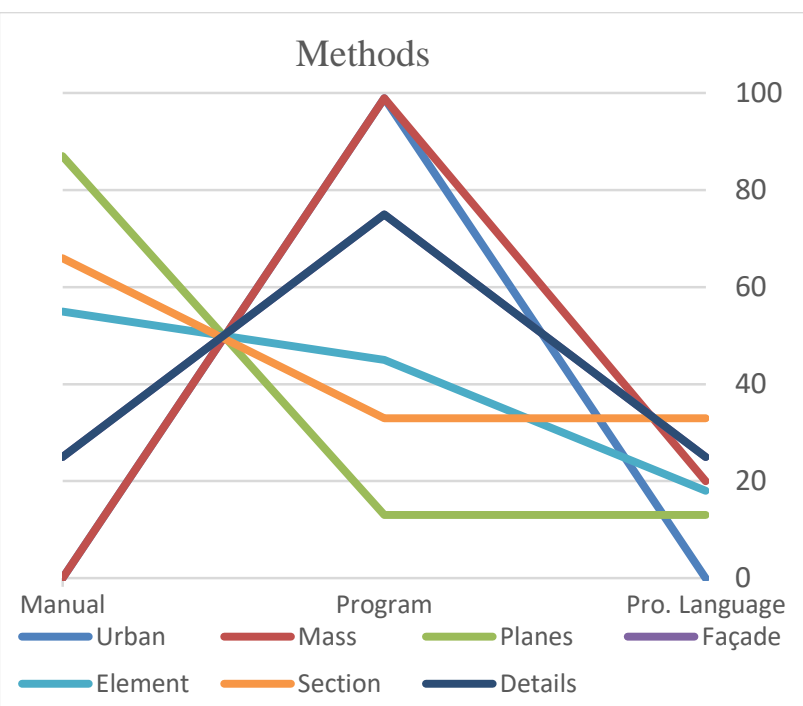

Figure 5 - Analysis of the Variables of Methods in the Studies

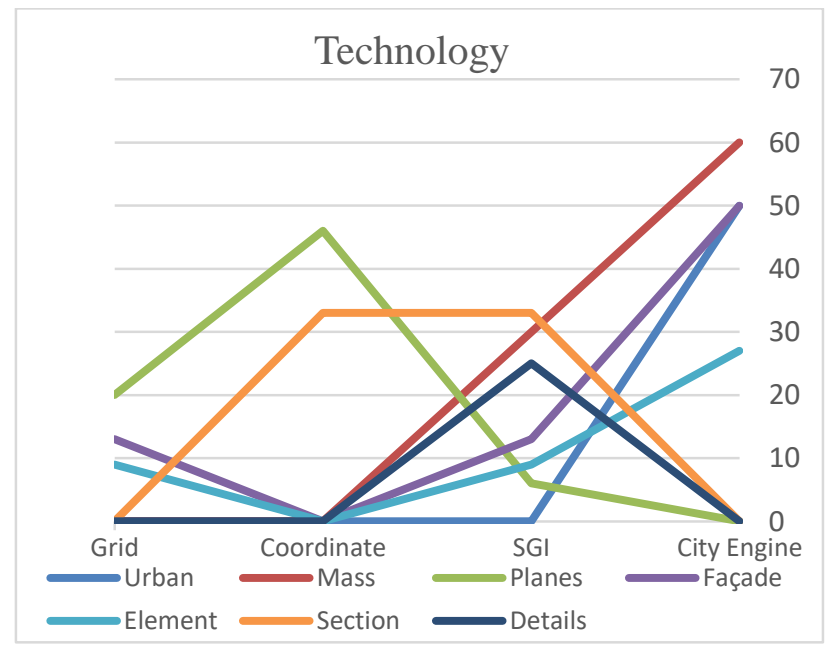

Figure 6 - Analysis of the Variables of Technology in the Studies

\section{Discussion the results}

The results show the correlation of the scope of the built heritage with the strategies of shape grammar in the cases studied and analysed as follows:

\subsection{General results}

- In general, although some of the results of the strategies are known in advance, the analytical approach adopted by the research has added more objectivity to the already existing knowledge. Besides, these results and the adopted methodology are necessary for the transition to the level of investing in the existing strategies.

- The results showed that the strategy of shape grammar varies according to the scope of the built heritage, due to the variation of information level and purpose of the shape grammar, but within the same scope. The results showed the conspicuous similarity of the strategy in dealing with the characteristics of built heritage, and this indicates the presence of specific strategies of shape grammar in each scope. This is what the research assumed in its hypothesis.

- In the parametric shape grammar, the parameters showed the possibility of creating the shapes according to the heritage context and its architectural structure, but in the standard shape grammar, the generation process is according to the applying of rules without mathematical analysis.

- The type of characteristics is related to the scope of the built heritage. This type of grammar determines the outward appearance of the element and studies the genotype according to its basic components. These characteristics are related to the standard shape grammar. Mathematical characteristics determine the placement of the element within the structure, proportions, and its dimensions. These characteristics are related to the parametric shape grammar, and these parameters restrict the mathematical characteristics of the element. Relational (spatial) characteristics analyze the relationship of an element to the other within the system. As for the functional characteristics, they are specific to the plans, which study the placement of the spaces to formulate the restrictions as a rule.

- The purpose of applying the shape grammar in the built heritage varies and it includes the analysis to determine the hidden structure of the traditional architecture; the classification to identify main categories of heritage elements with common characteristics for the documentation or creating libraries for these elements; the generation to produce new shape belonging to the same local architectural language; and, the evaluation to determine the belonging of the generated shape to the same architectural language.

- In the large scope of the built heritage, digital applications were employed to represent the built heritage because of the various restrictions of the shape grammar in this scope, these applications focused on automatic generation processes based on procedural modeling restricted by the rules.

- $\quad$ Regarding architectural details (such as motifs or ornamentations), shape grammar is used to produce new creative forms that belong to the built heritage language. Shape grammar is often converted into programmatic restrictions within a specific application of these details to produce new patterns with the same rules. 


\subsection{Results of the shape grammar strategies}

\subsubsection{Urban Scope:}

- $\quad$ Type of the shape grammar: These studies relied on applying the standard grammar that depends on the rules which include transformation operations on the initial shapes, and no type of parametric grammar applied in these studies.

- The Characteristics: Studies in this type focused on the morphological and structural characteristics of urban and in a lesser on spatial components and their distribution, without using the functional, mathematical, and relational characteristics.

- The Purpose: Most studies, in the urban scope, focused on structural analysis to generate parts of the urban district in the same architectural language, in addition to categorizing urban components.

- The Purpose: Most studies, in the urban scope, focused on structural analysis to generate parts of the urban district in the same architectural language, in addition to categorizing urban components.

- The Methodology: Urban studies used programs and applications.

- The strategy: Most studies relied on the procedural strategy in generating parts of the urban district, while others relied on a BottomTop strategy by determining the placement of the components.

- The Technology: Most studies used the City Engine program.

\subsubsection{Mass Scope}

- Type of shape grammar: These studies used parametric and standard grammar to produce different shapes in the same style.

- The Characteristics: These studies analyse the morphological, relational, spatial Characteristics to study the relational rule, some studies analyzed dimensions to determine the masses proportions.

- The Purpose: aims to classification and generation

- The Methodology: This approach has relied on programs.

- The strategy: The first is procedural for the generation process, and the second is the Bottom-Top to assemble the components.

- $\quad$ The Technology: Using the City Engine app in the procedural method.

\subsubsection{Plan Scope}

- $\quad$ Type of shape grammar: Standard shape grammar was applied in all studies, while parametric grammar was applied to generate an anew plan in the same language.

- The Characteristics: These studies are based on functional and spatial elements, in addition, other studies are based on the mathematical characteristics by parameters to study the properties of the plan.

- The Purpose: These studies seek to generate and classify plans according to the characteristic's analysis.

- The Methodology: Most of these studies relied on manual analysis drawing, while some used program languages to convert them into applications to classify them digitally.

- The strategy: The plans adopted two types strategies, the first is TopBottom which determines the overall shape and external borders, and the second is Bottom -Top, which determines the position of a central element or space then the adding other spaces that surround it.

- The Technology: In formulating the grammar, the X, Y coordinates are used to distribute the spaces by the grid or addition strategy.

\subsubsection{Facade Scope}

- $\quad$ Type of shape grammar: In this Scope, the standard shape grammar is used by applying rules on the shapes, and the parametric by parameters to generate the facades.
- The Characteristics: These studies analyzed the morphological characteristics of the facade in addition to the spatial properties and relational analysis to study the positions of elements in the facade.

- The Purpose: These studies are directed towards generating facades in the same language, and classifying them according to the characteristics.

- The Methodology: The representation of grammar was done by programming language, while other studies adopted the manual method derivation of grammar.

- The strategy: The addition strategy was adopted, in which the elements are added according to its relationships, in two ways, the first is the Bottom-Top by adding a central element, then adding the other, and the second is Top -Bottom which determines the external borders of the facade then adding the element gradually.

- The Technology: Most studies have used City Engine, while others presented applications for generating after formulating the grammar.

\subsubsection{Element Scope}

- Type of shape grammar: This study used standard grammar, by analyzing the elements morphologically then grouping them. Some studies used parametric grammar to generate new elements $=$.

- The Characteristics: Relying on analyzing the morphological characteristics mainly, then the mathematical characteristics to analyse the proportions, then relational analysis to determine the relationships between the element's component.

- The Purpose: These studies mainly aim to classify the architectural elements, then generating them and employing the grammar to evaluate the generation process.

- The Methodology: The studies rely on manual analysis to formulate the grammar; some applications and programs were employed for that by representing the grammar digitally such as GDL $\backslash$ OWL and others.

- $\quad$ Strategy: The studies used Bottom-Top derivation strategy, by adding parts of the elements gradually according to the grammar.

- The Technology: The City Engine program has been applied in several studies for the generation of architectural elements.

\subsubsection{Section Scope}

- Type of shape grammar: These studies are based on parametric and standard grammar in the process of generation and analysis.

- The Characteristics: They include the analysis of functional and spatial characteristics, in addition to the dimension values to determine the proportions of spaces.

- The Purpose: The studies aim to classify and generate designs.

- The Methodology: The grammar in these studies was formulated manually, and other studies used programs in the formulating process.

- The strategy: All studies depend on a Bottom- Top strategy by addition.

- The Technology: Relying on the coordinates to generate the sections of spaces because it is easy to deal with mathematical analysis.

\subsubsection{Details Scope}

- Type of shape grammar: This scope used standard and parametric grammar in formulating shape grammar.

- The Characteristics: It depends mainly on morphological and mathematical characteristics.

- The Purpose: These studies aim to generate designs.

- The Methodology: It depends on generation software.

- The strategy: It depends on the Bottom-Top strategy by addition. 
- The Technology: Some studies have employed a program.

\section{Conclusions}

The current research deals with strategies of applying the shape grammar in protecting the built heritage due to its cognitive value, which is complicated to conserve because of the difficulty of the representation of its deep architectural structure that requires analyzing and classifying of its component. The research presents a new approach of shape grammar for dealing with the built heritage due to its advantages in representing mathematically, morphologically, and topologically to formulate its characteristics and restrictions in a shape grammar form which are easy to deal with it in generating designs in the same architectural language.

The concepts of shape grammar in architecture were determined (including the type grammar, characteristics, approach of deriving rules, and techniques to generate the shapes), also the scopes of dealing with built heritage were determined according to the level of information (including urban, masses, plans, facades, sections, elements, and details scope) to set strategies of shape grammar in dealing with heritage.

The research highlights seven strategies, each of it represents a certain level of information, the first strategy is for the urban level in which the urban fabric is analyzed according to the morphological and typological characteristics of the fabric components, the second related to the building masses to formulate the relational grammar between the main components of the building, the third is the plan strategy which analysis the spaces in a plan mathematically and morphologically according to their functional characteristics to formulate the rules of placing the spaces, the forth is the facade strategy for generating facades in the same architectural language of the urban cultural context ,the fifth is the architectural sections which generate the spaces in building according to the mathematical analysis of section, the sixth is the element strategy to classify the heritage element and determine the genotype according to the morphological analysis, and the seven related to the architectural detail which determines the restriction as rules in shape grammar. These strategies are an important tool for designers to design in the same local architectural language, so it is one of the effective approaches to conserve the built heritage.

The importance of research is embodied in presenting specific strategies of shape grammar in representing the built heritage from the urban scope to the small details. These strategies enable the designer to aware of the deep structure of heritage architecture to design in the same architectural language, and this is one of the means of conserving Built Heritage.

\section{Recommendations}

- $\quad$ Providing a database for specialists who adopt shape grammar for local architecture, which is a valuable aspect in preserving the Built Heritage.

- Digitization the shape grammar in a computerized application to facilitate the deal with it to encourage architects on design in the local architecture style.

- Adopting the procedural methodology of shape grammar in modelling urban facades of destroyed historic cities (such as Mosul), as this methodology generates the facades rapidly for a large number of units in the same architectural language.

- Converting shape grammar into digital formats to generate designs automatically in two scopes at the same time such as the plan and façade scope, using AI to prevent clash between the grammars.
- Using shape grammar in designing new alternatives that have the same local architectural language and achieve contemporary functional requirements in heritage areas.

\section{REFERENCES}

[1] N. El Namara, A Proposed Approach for the Rehabilitation of Historical Buildings Possessing a Special Value in Gaza City Hammam Alsamra as a Case Study, AlQadisiyah Journal for Engineering Sciences, 7(4) (2014) 134-160.

[2] B. Feilden, Conservation of historic buildings, Routledge, 2007.

[3] ICOM, ICOMOS in, ICOMOS International Council on Monuments and Sites 1964.

[4] E.H. Al-Allaf, PREVENTIVE CONSERVATION AS A PROCEDURE FOR SAFEGUARDING MOSUL BUILT HERITAGE, DIYALA JOURNAL OF ENGINEERING SCIENCES, 7(2) (2014) 98-129.

[5] N.R. Lambe, A.R. Dongre, A shape grammar approach to contextual design: A case study of the Pol houses of Ahmedabad, India, Environment and Planning B: Urban Analytics and City Science, 46(5) (2019) 845-861.

[6] G. Stiny, W.J. Mitchell, The palladian grammar, Environment and planning B: Planning and design, 5(1) (1978) 5-18.

[7] M. Di Angelo, P. Ferschin, G. Paskaleva, Shape Grammars for Architectural Heritage, in, International Conference on Architecture and Urban Design, 2013.

[8] G. de Godoi, G. Celani, A study about facades from historical brazilian town using shape grammar, (2008).

[9] A.M.H. Abulnour, Protecting the Egyptian monuments: Fundamentals of proficiency, Alexandria Engineering Journal, 52(4) (2013) 779-785.

[10] D. Oreni, R. Brumana, A. Georgopoulos, B. Cuca, HBIM library objects for conservation and management of built heritage, International Journal of Heritage in the Digital Era, 3(2) (2014) 321-334.

[11] S. Lagomarsino, N. Abbas, C. Calderini, S. Cattari, M. Rossi, R.G. Corradini, G. Marghella, F. Mattolin, V. Piovanello, Classification of cultural heritage assets and seismic damage variables for the identification, WIT Transactions on the Built Environment, 118 (2011) 697-708.

[12] N. Saleeb, M. Marzouk, U. Atteya, A comparative suitability study between classification systems for BIM in heritage, Building Information Systems in the Construction Industry, (2018) 137.

[13] A. H Al-Jameel, M. D Younis, R. M Hamed, Using Standard Shape Grammars to Generate The Basic Types of Congregational Mosques, AL-Rafdain Engineering Journal (AREJ), 22(5) (2014) 118-135.

[14] D. Benrós, A generic housing grammar for the generation of different housing languages: a generic housing shape grammar for Palladian villas, Prairie and Malagueira Houses, UCL (University College London), 2018.

[15] T.M. de Jong, D. Van Der Voordt, Ways to study and research: urban, architectural, and technical design, Ios Press, 2002.

[16] P. Müller, T. Vereenooghe, A. Ulmer, L. Van Gool, Automatic reconstruction of Roman housing architecture, in: International Workshop on Recording, Modeling and Visualization of Cultural Heritage, Balkema Publishers (Taylor \& Francis group), 2005, pp. 287-297.

[17] W. Zhu, D. Wang, B. Eynard, M. Bricogne, S. Remy, Procedural Approach for 3D Modeling of City Buildings, in: IFIP International Conference on Product Lifecycle Management, Springer, 2015, pp. 137-148.

[18] M. DI ANGELO, P. FERSCHIN, Procedural Modelling of Traditional Balinese Settlements, (2012).

[19] L. Sass, A Palladian construction grammar-design reasoning with shape grammars and rapid prototyping, Environment and Planning B: Planning and Design, 34(1) (2007) 87-106.

[20] T. Trescak, M. Esteva, I. Rodriguez, A shape grammar interpreter for rectilinear forms, Computer-Aided Design, 44(7) (2012) 657-670.

[21] B. Tepavčević, V. Stojaković, Procedural modeling in architecture based on statistical and fuzzy inference, Automation in construction, 35 (2013) 329-337.

[22] S.M. Şener, E. Görgül, A shape grammar algorithm and educational software to analyze classic Ottoman mosques, A| Z ITU Journal of the Faculty of Architecture, 5(1) (2008) 12-30.

[23] E. Colucci, V. De Ruvo, A. Lingua, F. Matrone, G. Rizzo, HBIM-GIS integration: From IFC to cityGML standard for damaged cultural heritage in a multiscale 3D GIS, Applied Sciences, 10(4) (2020) 1356.

[24] G. Çağdaş, A shape grammar: the language of traditional Turkish houses, Environment and Planning B: Planning and Design, 23(4) (1996) 443-464.

[25] B.H. Eilouti, M.J. Hamamieh Al Shaar, Shape grammars of traditional Damascene houses, International Journal of Architectural Heritage, 6(4) (2012) 415-435. 
[26] O.B. AbdulRaheem, O.A. Rayis, DESIGN OF GENERATIVE MODEL FOR THE LANGUAGE OF TRADITIONAL SUAKIN USING PARAMETRIC SHAPE GRAMMAR.

[27] E. Andaroodi, F. Andres, A. Einifar, P. Lebigre, N. Kando, Ontology-based shape-grammar schema for classification of caravanserais: a specific corpus of Iranian Safavid and Ghajar open, on-route samples, Journal of Cultural Heritage, 7(4) (2006) 312-328.

[28] B.H. Eilouti, A.M. Al-Jokhadar, A generative system for Mamluk madrasa formmaking, in: Nexus Network Journal, Springer, 2007, pp. 7-29.

[29] M.B. Colakoglu, Design by grammar: algorithmic design in an architectural context, Massachusetts Institute of Technology, 2000.

[30] S.-c. Chiou, Computational Considerations of Historical Architectural Analysis, Swiss Federal Institute of Technology Zurich.

[31] D. Kitsakis, E. Tsiliakou, T. Labropoulos, E. Dimopoulou, Procedural 3D modelling for traditional settlements. The case study of central zagori, The International Archives of Photogrammetry, Remote Sensing and Spatial Information Sciences, 42 (2017) 369.

[32] E. Calogero, J. Kaminski, D. Arnold, Using procedural modeling to explore alternative designs for the louvre, Journal on Computing and Cultural Heritage (JOCCH), 6(4) (2013) 1-22.

[33] G. de Godoi, G. Celani, A study about facades from historical brazilian town using shape grammar.

[34] W. Ria In Search of "Mamminasata Style": Model for the Application of Local Architectural Characteristics for Contemporary Design based on Shape Grammar, of International Seminar on Local Wisdom in Global Era., (2011).

[35] F. Coutinho, E.C. e Costa, J.P. Duarte, M. Kruger, A shape grammar to generate Loggia Rucellai, (2013).

[36] D.A.A. Al-Kazzaz, Shape grammars for hybrid component-based design, University of Strathclyde, 2011.

[37] P.F.C.C. D'Oliveira, A detail shape grammar. Using Alberti's column system rules to evaluate the longitudinal elevation of the nave of Sant'Andrea church generation, Artificial Intelligence for Engineering Design, Analysis and Manufacturing: AI EDAM, 32(3) (2018) 295-307.

[38] M.M. Marzouk, N. Saleeb, M. El Sharkawy, A.S. Eid, M.R. Ali, M.S. Metawie, Classification system for Egyptian heritage buildings, in: 2018 IEEE International Conference on Industrial Engineering and Engineering Management (IEEM), IEEE, 2018, pp. 854-858.

[39] E.H. Ismaeel, Synthetic CharacteristicsOf Traditional Historic Houses Entrances In Old City Of Mosul, AL-Rafdain Engineering Journal (AREJ), 22(3) (2014) 63-83.

[40] E. Garavaglia, A. Anzani, F. Maroldi, F. Vanerio, Non-Invasive Identification of Vulnerability Elements in Existing Buildings and Their Visualization in the BIM Model for Better Project Management: The Case Study of Cuccagna Farmhouse, Applied Sciences, 10(6) (2020) 2119.

[41] S. Said, M.R. Embi, A parametric shape grammar of the traditional Malay longroof type houses, International journal of architectural computing, 6(2) (2008) 121-144.

[42] S.-c. Chiou, R. Krishnamurti, The grammar of Taiwanese traditional vernacular dwellings, Environment and Planning B: Planning and Design, 22(6) (1995) 689720.

[43] Z. Sayed, H. Ugail, I. Palmer, J. Purdy, C. Reeve, Parameterized shape grammar for generating $\mathrm{n}$-fold Islamic geometric motifs, in: 2015 International Conference on Cyberworlds (CW), IEEE, 2015, pp. 79-85.

[44] A.Ö. Yavuz, Ö. Sağıroğlu, Reviewing the Bricks Used in The Traditional Architecture with The Shape Grammar Method, Gazi University Journal of Science, 29(4) (2016) 741-749. 